\title{
"Natural" Music of Ivan G. Sokolov: Sonata for Cello and Piano
}

\author{
Natalia Ruchkina \\ Department of Music Theory \\ The State Institute of Arts Studies \\ Moscow, Russia \\ E-mail: n.ruchkina@mail.ru
}

\begin{abstract}
The article is devoted to the study and understanding of a set of ideas typical for works of Ivan G. Sokolov (1960) at the turn of the centuries. After an experimental conceptual period in the late 1980s and mid$1990 \mathrm{~s}$ - the composer tends to "natural" music, as he calls it. The study of the Sonata for Cello and Piano (2002) shows his "natural" music based on the traditions, as it can be noticed in melodic curves and movements order (I-IV), appealing to the familiar styles of previous days. The selected musical elements represent a set of topoi, which are common for musical art of the $19^{\text {th }}$ and the first half of the $20^{\text {th }}$ centuries. The basis of such composition can be seen in the scientific attitude, which means the research "the movement of thoughts" (Sokolov) of other composers, particularly, of Shostakovich, Prokofiev, Rachmaninoff. As a result, the "simplicity" of musical language presents a consequence of "naturalness", which is understood as something habitual and recognizable. The dialogue with "beloved precursors" (Boris Pasternak) moves the composer's individuality to the periphery, where appears in the simultaneous existence of intertextual layers, classical forms, minimalistic interpretation of time and space, "weakened" energetic intensity. The conceptual element moves to another level within the bound of "natural power of musicmaking" (Sokolov).
\end{abstract}

Keywords - musical art of the late $20^{\text {th }}-$ early $21^{\text {st }}$ centuries; Ivan Sokolov; simplicity; "natural" music; conceptuality; polystylistics; intertextuality; dialogue; author's individuality

\section{INTRODUCTION}

The art of Russian composer Ivan G. Sokolov (1960) has been marked by a significant evolution - from the conceptual opuses in the late 1980 s - early $1990 \mathrm{~s}^{1}$ the composer arrives at "natural music," as he calls it. The Sonata for Cello and Piano, written in 2002 is a pure example of this ${ }^{2}$. This raises the question how does the composer understand this notion and how is it presented in the Sonata. The article on the example of Cello's opus, tries to define and understand the

\footnotetext{
${ }^{1}$ In this period, his art turns to the ideas of P. Boulez, M. Kagel, J. Kage, M. Feldman and K. Stockhausen, as Sokolov rushes to freedom, which, he believes, the foreign composers treated with time and space.

${ }^{2}$ The composition presented in the year of its creation at the music festival dedicated to Shostakovich in Seattle.

URL:http://www.russianseattle.com/MusicDubinets/news_2003_01_Shosta kovich.htm
}

spectrum of ideas that formed in the art of Ivan Sokolov by the beginning of the $20^{\text {th }}$ century.

\section{Dialogue WITH THE "BELOVED PRECURSORS”}

During his work, the composer noticed that he was subconsciously reflecting upon Shostakovich ${ }^{3}$. According to the author, these thoughts were provoked by the composer's effort "to come back, in some new manner, to the musical world where his childhood and youth had passed - to the world of Shostakovich, Prokofiev, Rachmaninoff and Mahler" ". It is not surprising that he strives to associate with the "beloved precursors" (Boris Pasternak) since similar dialogues can be seen, probably, in any other composer's art. Oftentimes, a composer of different generation gives an impetus to another composer's art, and as this occurs, it finds its way into different compositions of the latter.

The starting point for Sokolov's work became the sort of "worn out" and "cranked out" 5 musical phrases, "streamlined basis of some traditional melodical turns, sharpened through centuries in a complex composer's brain". 6 Traditional roots is expressively appearing in the order of movements, their shape; composed directly to the classic canon - sonata allegro, slow second part, scherzo and hypothetical final". 7

The beginning of the sonata refers to Shubert and Shostakovich at the same time, since, as the musician assumes, the opening melody in the part of the cello reminds of the First Impromptu by Shubert and together with that, of the Viola solo from the First quartet by Shostakovich. "Fig. 1", "Fig. 2", "Fig. 3".

\footnotetext{
${ }^{3}$ E. Dubinets, "Mozart does not choose his homeland. Music of modern Russian foreign community", M.: Muzizdat. 2016. P. 219.

${ }^{4}$ I. Sokolov, From annotation to the CD. Russian and Czech duos and trios by Ivan Sokolov, Viktor Kalabis \& Jan Vicar. 2010. Ariel Ventures. Alabama.

${ }^{5}$ E. Dubinets, Ibid. p. 220

${ }^{6}$ E. Dubinets, Ibid. p. 220

${ }^{7}$ I. Sokolov, From the annotation to the CD. Russian and Czech duos and trios by Ivan Sokolov, Viktor Kalabis \& Jan Vicar. 2010. Ariel Ventures. Alabama.
} 


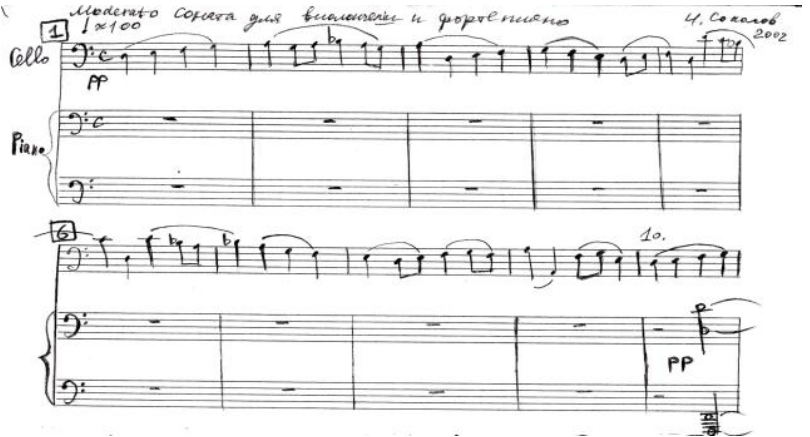

Fig. 1. I. Sokolov. Sonata for Cello and Piano, I movement

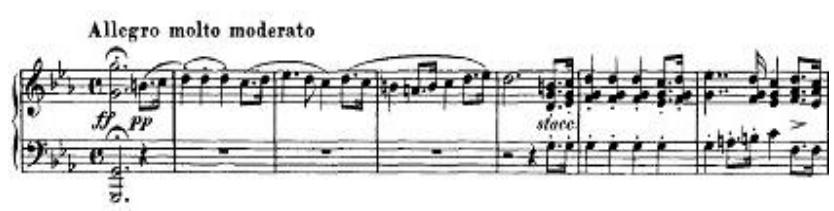

Fig. 2. F. Schubert. Impromptu №1 op. 90

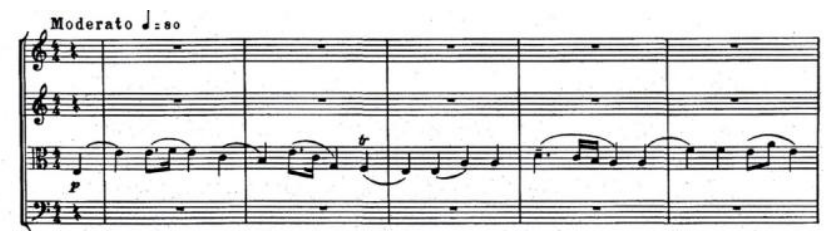

Fig. 3. D. Shostakovich. Quartet №1 op. 49, II movement

As can be seen, the "association" with the mentioned composers' music should be perceived under very general assumptions. The Sonata's beginning, according to the researcher, can be referred to the compositions by D. Shostakovich opening the philosophical monologue of the cello. "Fig. 4", "Fig. 5".

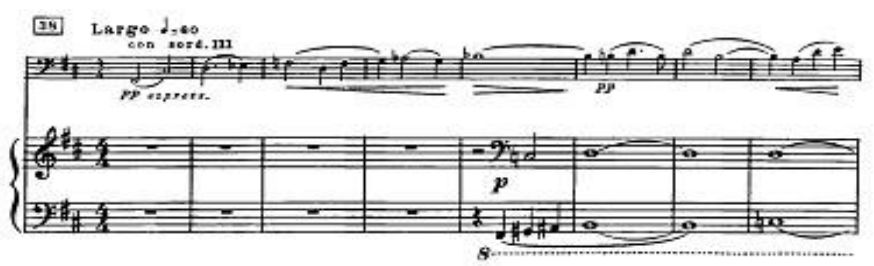

Fig. 4. D. Shostakovich. Sonata for the Cello and Piano, III movement
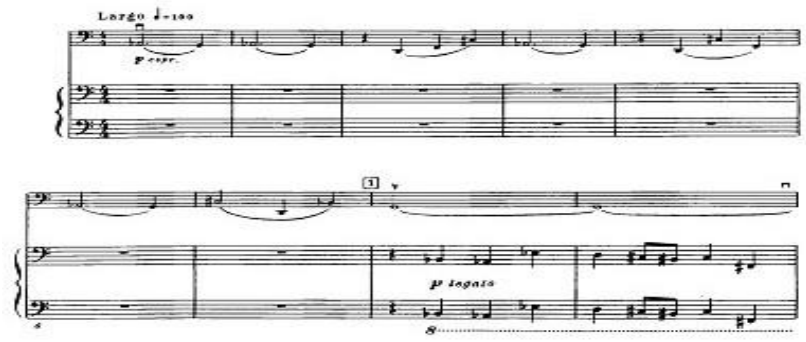

Fig. 5. D. Shostakovich. Cello Concerto №2 op. 126, III movement

There is no escaping the impression that the composer deliberately avoids particular recognizable quotations and melodical turns. All of them are somewhat alike, existing only on the edge of the identification. According to Sokolov, his composition addresses several epochs and styles: "the second part - Poulenc, the development - Myaskovsky and Beethoven; Shostakovich - the reprise and in code. In the second part - Prokofiev, Sidelnikov and even Tchaikovsky. In the connecting part of the second part and in the third part - Mahler, and then, surprisingly, Schumann, Mendelssohn and Rachmaninoff" ${ }^{8}$. Again, the association with the authors mentioned above is extremely relative and likely as a subtle implication. "Fig. 6", "Fig. 7", "Fig. 8", "Fig. 9", and "Fig. 10 ".

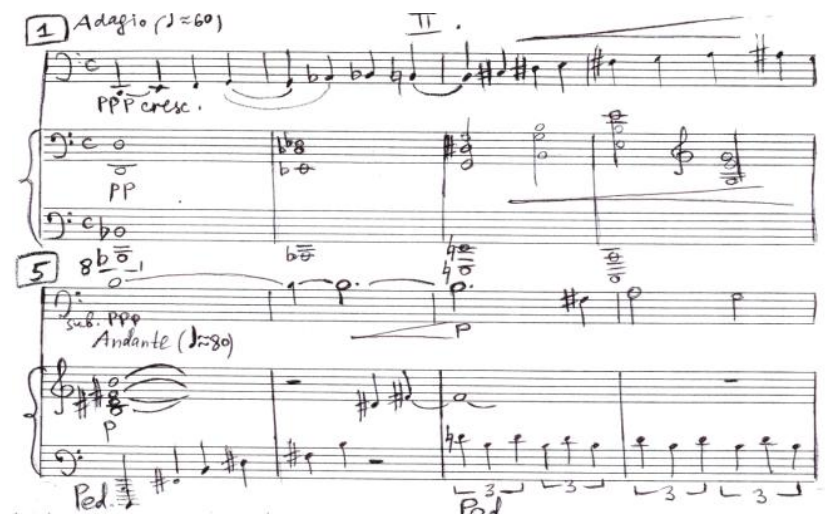

Fig. 6. I. Sokolov. Sonata for the Cello and Piano, II movement

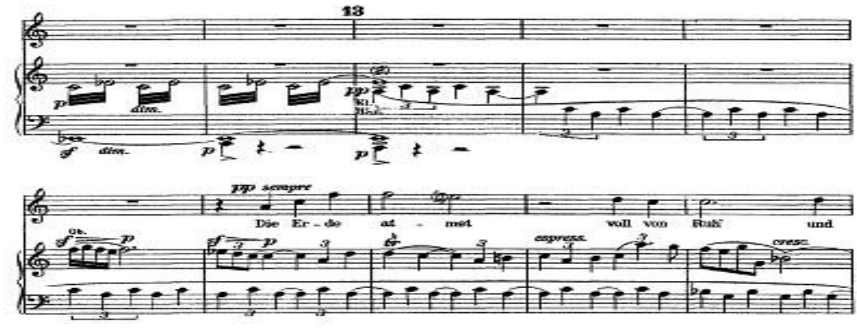

Fig. 7. G. Mahler "Song about the land" 6. Der abschied

Allusions and false allusions gleam in kaleidoscopic fusion, making us divine, hesitate and anticipate, and yet fail to catch the origin of versatile and escaping musical motives.

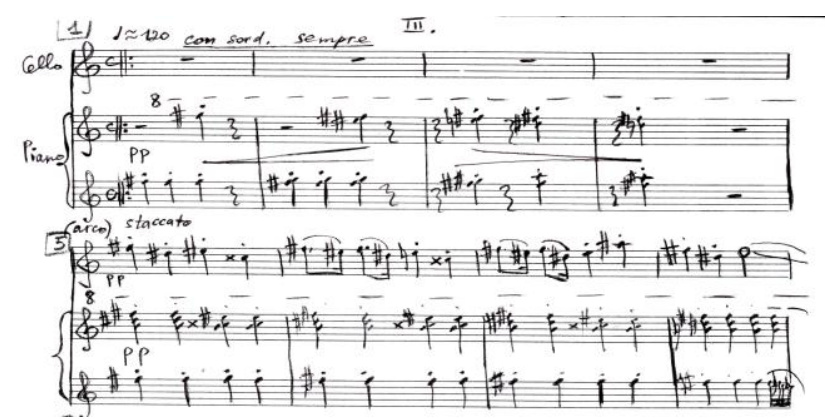

Fig. 8. I. Sokolov. Sonata for the Cello and Piano, III movement 


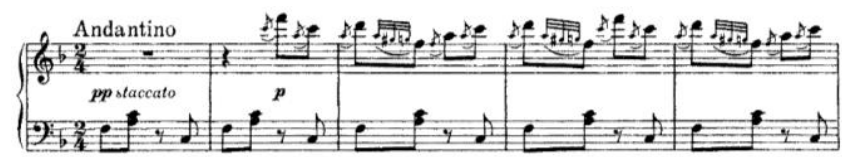

Fig. 9. P. Tchaikovsky, Bluebird and Princess Florina. "Sleeping Beauty"
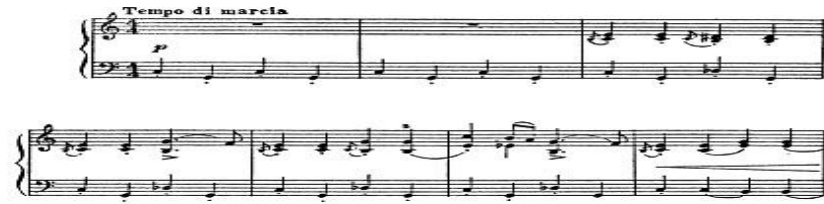

Fig. 10. S. Prokofiev, Music for children. March. Op. 65 (10).

The sound of the finale, due to mainly quiet dynamics and despite of the presence of $\mathrm{f}$, ff and even fff, looks like a "distant" and stereophonic effect. "Fig. 11"

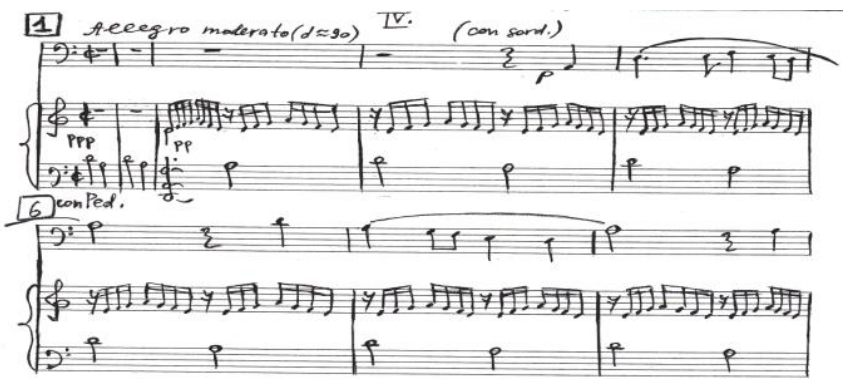

Fig. 11. I. Sokolov. Sonata for the Cello and Piano, IV movement

Turning to the main repeating motive a-d, Sokolov continues to pursue answers to the long-exciting question concerning the Viola Sonata by Shostakovich - "what kind of sense is hidden in this simple, as it seems, quartal intonation la-re $(a-d-N . R$. $)$ ?" 9 He finds the answer in the final of the set of Alexander Block's poems for pianoforte op.127. "Sometimes it seems to me - notices the author - it is a hell (since $a$ and $d$ together means hell $[a d]$ in Russian N.R.)". ${ }^{10}$ Presence of this intonation in many compositions of Shostakovich excites Sokolov - Viola Sonata, Fifth Symphony, prelude №19 from the cycle "24 Preludes and Fugas." Applying these allusions, Sokolov generally tried "not to focus on this, but to forget what it looks like, and develop the material in its natural direction of its own existence; tried not to follow Rachmaninoff, but touch slightly"11.

\section{COMPOSITION ASPECTS}

In the instance of Sokolov's Cello Sonata, it is hard to escape a conclusion that the composer thinks in different but rather similar musical "formula-blocks". Sokolov in his composition turns to a sort of ready-made objects, purposefully eroding their boundaries. Suchwise Sokolov moves all musical material of the composition to the level of "general forms". He turns to recognizable style elements

\footnotetext{
${ }^{9}$ I. Sokolov, "To the direction of alt sonata”, Musical Academy №3, 2006. p. 48.

${ }^{10}$ I. Sokolov, Ibid.

${ }^{11}$ E. Dubinets, Ibid, p. 220.
}

representative of the composers living before, genuinely assembling the elements in a special way. Such combination principle bases on the arrangement together of the affectively similar and close musical elements. All together, they present the set of topoi intrinsic to the musical art of the $19^{\text {th }}$ century. As a result, Sokolov's "natural" music becomes somewhat habitual and recognizable, conforming the comment that "we have heard this music somewhere, but it does not have any direct quotations in it" $"$.

In the conditions of chosen modus operandi the musician is randomly combining recognizable "formula-blocks", believing that it is music that composes the composer" 13 . Having defined the rules and borders of the personal "play of chance," he releases "deep mechanisms of fantasy, relative to subconscious game of the nature" ${ }^{14}$. The chance in this context stays within the confines of resemblance and appeals to the experience that Sokolov gets while connecting with other composers' certain musical material.

Unveiling such kind of interconnections, consequently, Sokolov was working out the idea of the composition by means of his research capability. In a loose sense, this contradicts a "play of chance" and returns us to the "conceptual layer". Literally, the "style principle of conceptual composition presents its quasi-romanticized form or scheme, filled with senseless words" $"$. This expression can be referred to the music, but "senseless words" should be read as "clichéd" musical elements, mentioned by the composer. The second usage of "any shabby and dead clichéd expressions $\langle\ldots>$, which are popular quotations" $" 16$ is an inevitable part of the conceptualism.

Noteworthy that in his composition, Sokolov follows the way, which he has found in the analytical interpretations of music, and, in particular, in Viola Sonata of Shostakovich. In his article about Shostakovich and concerned with the "research of author's way of thinking" Sokolov points to the musician's special love for quotations. The composer reacts to "conceptual layer" of Viola Sonata, noting that Shostakovich uses a special system of quoting, which presents his artistic approach, including both the world musical culture and auto-quotations. In the Viola Sonata Sokolov finds all major themes of all Shostakovich symphonies, which are heard "as through a mist of eternity, smooth: without any rhythm, sometimes without a precise repetition of pitch, in changed tones" $"$.

As to the Cello Sonata music, there are many "quiet" places, and yet, despite this, there are signs $\mathrm{f}$ and $\mathrm{ff}$ in the score, the sound has no explicit shape and does not become concrete and stable. The climaxes do not make an impression of really existent, without crossing "the mist of eternity",

\footnotetext{
${ }^{12}$ E. Dubinets, Ibid. p. 220.

${ }^{13}$ E. Dubinets, Ibid. p. 212

${ }^{14}$ E. Bobrinskaya, "Russian avant-garde: boarders of art", M.: New literature review, 2006. p. 181.

${ }^{15}$ N. Seim, "Vladimir Sorokin - mind, honor and conscience of postmodern epoch", 2007, Lund, Sweden, p. 39.

${ }^{16}$ N. Shrom, "Literature of modern Russia 1987-2003", M.: Abraziv, Retonika-A, p. 55.

${ }^{17}$ I. Sokolov, Ibid, p. 43.
} 
since everything is not real, a little artificial and toylike". ${ }^{18}$ It feels like Sokolov, resorting to the "shabby" and "clichéd" musical gestures, erodes their boarders, extending from them far away with an outside look.

The absence of tension, conflicts, narrative manner of exposition of musical material, long flat "edges" of lengths, thematic repetitions - all this gives a kind of "minimalistic shadow." One might get the impression, that it is "toyish" to address the abovementioned composers' style, that from the inside this music is close to the "minimalism," in which the most important are musical-philosophical bases and a composition is free of hierarchy, mutual, climaxes, development and contrasts.

At some extent, this is assonant to the art and ideas of $\mathrm{M}$. Feldman, whose compositions offer "no traditional drama, but merely the immersion into certain "state," with no contrasts and with just a slight trembling of musical shades" "19. Strangely, but in Sokolov's Sonata music the time is static. Feldman, for example, admitted, that he is closely connected with statics. The American composer calls such stance frozen and yet vibrating ${ }^{20}$. Sokolov's compositions give the feeling of motionless time, somewhat durée ${ }^{21}$.

The composer perceives the situation in music at the present day as of the age of Beethoven and Shubert, and then, of Shostakovich, whereat "compositions of immense difficulty, the highly technological things exist with a huge intention towards the simplicity"22. Composed intentionally in a "simple" style, the Sonata for Cello and Piano opposes the avant-garde "difficult" period in Sokolov's art. The composer addresses to "ready-made forms", using them as a structural material for his compositions, since "quoting, simulation, and re-appropriation - all these are not just terms of modern art, but constitute its essence"23. "Simplicity" is coming of "naturalness".

Special features mark the play of styles in Sokolov's compositions. The composer does not address to direct quotes and allusions, though mentions them in his commentaries concerning the primary source. As for his Sonata for Cello and Piano, the original stays in a mist, does not have certain and sharp shapes and stays on the edge of resemblance with alike compositions.

\section{FeATURES OF SOKOLOV's “NATURAL” MusiC}

A dialogue-like writing is not new, but every time it has many differences. Such dialogue begins to sound especially

\footnotetext{
${ }^{18}$ E. Dubinets, Ibid, p. 220.

${ }_{19}$ A. Lyakhova, "Late art of Morgan Feldman: between the idea and realization", Master's thesis, Gnessin Russian Academy of Music, Moscow, 2014 , p. 18.

${ }^{20}$ See: M. Feldman, "Give My Regards to Eighth Street", Collected Writings of Morton Feldman, ed. B. Friedman, Cambridge, Exact Change, 2000, p. 184; A. Lyakhova, "Late art of Morgan Feldman: between the idea and realization. Master's thesis, Moscow, Gnesins Russian Academy of Music, 2014, p. 18.

${ }^{21}$ See: T. Tsaregradskaya, "Time and rhythm in Olivier Messiaen art", Moscow, Klassika-XXI, 2002.

${ }^{22}$ E. Dubinets, Ibid, p. 220.

${ }^{23}$ J. Baudrillard, "Esthetic Illusion and Disillusion", Paris, 1997. URL: http://my.arcto.ru/public/9bodrial.htm
}

vividly at the close of the 19th century, when all composers began to refer to the style of musical compositions of the $17^{\text {th }}$ $-18^{\text {th }}$ centuries $^{24}$. In the period of avant-garde, the authors chose to escape such dialogue, which is almost impossible. For Russian music of the 1960s - 1970s, the tendency became very popular; the sense of it reflects the notion polystylistics. It is generally accepted that A.G. Schnittke introduced this term in musical study. This has become an opening of further research developments on "similar events in music of other composers" voices of different musical periods, leads to a personal dialogue with everybody. On the turn of the $20^{\text {th }}-21^{\text {st }}$ centuries, the dialogueness provided the basis for modern mosaic culture. It appeared in a form of a composer's technique. Gradually the polystylistics took on new significance, characterizing the artistic thinking of the later half of the foregone century. Its understanding becomes wider, more diverse and meaningful. Sokolov's aspiration to dialogue with composers of his childhood and youth in a new manner suggests new vision of the polystylistics by the musician. In the Sonata for Cello, we see that Sokolov does not follow the footsteps of Stravinsky or Schnittke, but tends to a free music making." This sphere gives the composer a new artistic platform.

All this corresponds to such contemporary event as the downshifting, similar to simple living. The downshifting in our case can be interpreted as a slowdown or weakening of any process, an escape from imposed by the world patterns of success, an attempt of subtraction of a person from his human essence in the name of life harmony and heartsease. It is safe to say that Sokolov, going to the world of allusions, his personal illusions and fantasies, is leaving the temple of fame for the sake of success of "nonpublic" music making. In some degree, this resonates the views of Valentin Silvestrov, the main of which is an ambition for a slowrhythm lifestyle, for zest to every moment of life and for lyricism. It is reflected in a composing style with musical intonations that seem to be banal. He calls his style "weak" Silvestrov notices, while "touching a new sound world" 27 , he had "realized the idea of melody made in almost unnoticeable, irrational way" 28 . His expression resembles Sokolov's thoughts. The latter is running back to his youth, showing his wish not to let it go. Here lies the importance of "block-making" from the musical material elements of the composition. Moreover, the things, which have been earlier perceived as criticism and negative estimation, now are made by the author on purpose, becoming not just the basis of the traditions, but sort of a challenge.

\footnotetext{
${ }^{24}$ For example, "Intermezzo in a classical style" by Mussorgsky (1862),

“Old Minuet” by Ravel (1895), "Classical Symphony” by Prokofiev (1917), "Sonatine bureaucratique" by Satie (1917).

${ }^{25}$ T. Dzun, "The symphonic art of Alfred Schnittke: an experience of intertextual analysis", Master's thesis, Moscow Tchaikovsky Conservatory, 2003 , p. 4.

${ }^{26}$ See: V. Silvestrov, "Waiting for Music", Lections and conversations, materials of meetings organized by S. Pilyutikov, Kiev: Dukh i litera, 2012.

${ }^{27} \mathrm{~V}$. Silvestrov, Music is the signing of the world about itself... Personal interviews and looks from aside: Talks, articles, letters/ author of the articles and compiler M. Nestieva. Kiev, 2004, p.114.

${ }^{28}$ Ibid.
} 


\section{CONCLUSION}

Intertextuality, music of the Sonata is traced on the level of an internal process, reproducing the combination of someone's already existing texts, which are tuned to the emotional frequency set by Sokolov. Applying "different styles, different epochs and different thoughts" (I. Sokolov), the author, as he believes, drifts away from the "channel of ideas" and steps into the "natural environment of musicmaking". On purpose or not, Sokolov applies in his art the "mindset" that was found in other composers' compositions. The author's individuality is pushed into the background, manifesting itself in intertextual layers, classical forms, minimalistic explanation of time and space and "weakened" energetic intensity. All this is shifting the musical concept to another sphere.

\section{REFERENCES}

[1] E. Bobrinskaya, "Russian avant-garde: the boundaries of art", M.: New Literary Review, 2006. p. 304.

[2] J. Baudrillard, "Aesthetic Illusion and Disillusion", Paris. 1997. URL: http://my.arcto.ru/public/9bodrial.htm

[3] T. Dzjun, "Symphonic creativity of Alfred Schnittke: the experience of intertextual analysis", PhD, M.: 2003.

[4] E. Dubinets, "Mozart doesn't choose the Fatherland. About the music of contemporary Russian composers abroad", M.: 2016. p. 312.

[5] C. Levi-Strauss, "Prehistoric thinking", Moscow, 1999, p. 392.

[6] A. Lyakhova, "Later creativity of Morton Feldman: between the idea and implementation", PhD, Moscow, 2014.

[7] V. Martynov, "The end of time of composers", Afterword by T. Cherednichenko, M.: 2002, URL: www.rp-net.ru

[8] V. Silvestrov, "Waiting for music", Lectures and conversations, the materials of meetings organized by S. Pilyutikov. K., 2012, p. 368.

[9] V. Silvestrov, "Music is the singing of the world about itself.. Personal interviews and looks from aside: Talks, articles, letters", author of articles and compiler M. Nestieva, Kiev, 2004, p. 265.

[10] I. Sokolov, Annotation, CD, Russian and Czech duos and trios by Ivan Sokolov, Viktor Kalabis \& Jan Vicar, 2010, Ariel Ventures, Alabama.

[11] I. Sokolov, "Moving towards understanding of the Sonata for Viola by Shostakovich”, Musical Academy, №3, 2006, pp. 42-48.

[12] T. Tsaregradskaya, "Time and rhythm in the creativity of Olivier Messiaen", M.: Klassika-XXI, 2002, p. 376.

[13] A. Schnittke, "Tendencies of polystylistics in contemporary music", Music in the USSR, 1988, April-June, M.; pp. 22-24.

[14] N. Shrom, "Literature of contemporary Russia 1987-2003", M.: Abraziv, Retorika-A, 2005, p. 224.

[15] M. Feldman, "Give My Regards to Eighth Street", Extended collection of Morton Feldman, ed. B.H. Friedman, Cambridge: Exact Change, 2000, p. 222.

[16] N. Seim, "Vladimir Sorokin - mind, honour and conscience of the epoch", Lund, 2007, p. 101. 